\title{
Operando Insight into the Correlation between the Structure and Composition of CuZn Nanoparticles and Their Selectivity for the Electrochemical $\mathrm{CO}_{2}$ Reduction
}

Hyo Sang Jeon, ${ }^{\dagger}$ Janis Timoshenko, ${ }^{\dagger}$ Fabian Scholten, ${ }^{\dagger}$ Ilya Sinev, ${ }^{\dagger}$ Antonia Herzog, ${ }^{\dagger}$ Felix T. Haase, ${ }^{\dagger}$ and Beatriz Roldan Cuenya*, ${ }^{*}$ (i)

${ }^{\dagger}$ Department of Interface Science, Fritz-Haber Institute of the Max-Planck Society, 14195 Berlin, Germany

${ }^{\ddagger}$ Department of Physics, Ruhr-University Bochum, 44780 Bochum, Germany

\section{Supporting Information}

ABSTRACT: Bimetallic CuZn catalysts have been recently proposed as alternatives in order to achieve selectivity control during the electrochemical reduction of $\mathrm{CO}_{2}$ $\left(\mathrm{CO}_{2} \mathrm{RR}\right)$. However, fundamental understanding of the underlying reaction mechanism and parameters determining the $\mathrm{CO}_{2} \mathrm{RR}$ performance is still missing. In this study, we have employed size-controlled $(\sim 5 \mathrm{~nm}) \mathrm{Cu}_{100-x} \mathrm{Zn}_{x}$ nanoparticles (NPs) supported on carbon to investigate the correlation between their structure and composition and catalytic performance. By tuning the concentration of $\mathrm{Zn}$, a drastic increase in $\mathrm{CH}_{4}$ selectivity [ 70\% Faradaic efficiency (F.E.)] could be achieved for $\mathrm{Zn}$ contents from 10 to 50, which was accompanied by a suppression of the $\mathrm{H}_{2}$ production. Samples containing a higher $\mathrm{Zn}$ concentration displayed significantly lower $\mathrm{CH}_{4}$ production and an abrupt switch in the selectivity to CO. Lack of metal leaching was observed based on quasi in situ X-ray photoelectron spectroscopy (XPS). Operando X-ray absorption fine

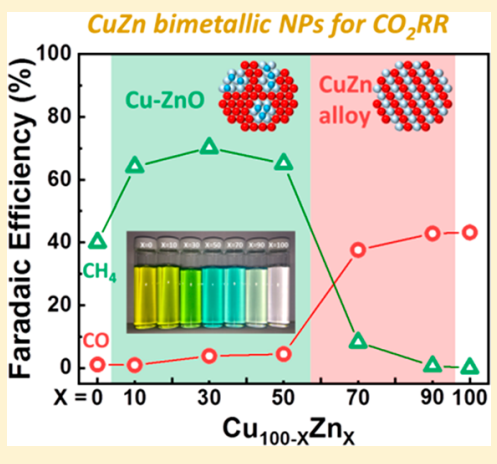
structure (XAFS) spectroscopy measurements revealed that the alloying of $\mathrm{Cu}$ atoms with $\mathrm{Zn}$ atoms takes place under reaction conditions and plays a determining role in the product selectivity. Time-dependent $\mathrm{XAFS}$ analysis showed that the local structure and chemical environment around the $\mathrm{Cu}$ atoms continuously evolve during $\mathrm{CO}_{2} \mathrm{RR}$ for several hours. In particular, cationic $\mathrm{Zn}$ species initially present were found to get reduced as the reaction proceeded, leading to the formation of a CuZn alloy (brass). The evolution of the $\mathrm{Cu}-\mathrm{Zn}$ interaction with time during $\mathrm{CO}_{2} \mathrm{RR}$ was found to be responsible for the change in the selectivity from $\mathrm{CH}_{4}$ over $\mathrm{Cu}-\mathrm{ZnO}$ NPs to $\mathrm{CO}$ over $\mathrm{CuZn}$ alloy NPs. This study highlights the importance of having access to in depth information on the interplay between the different atomic species in bimetallic NP electrocatalysts under operando reaction conditions in order to understand and ultimately tune their reactivity.

\section{INTRODUCTION}

The electrochemical reduction of $\mathrm{CO}_{2}\left(\mathrm{CO}_{2} \mathrm{RR}\right)$ into useful chemicals and fuels has received much attention as a means to build carbon recycling systems. ${ }^{1,2}$ However, efficient and inexpensive electrocatalysts are still required to reduce the thermodynamically stable $\mathrm{CO}_{2}$ molecule while suppressing the $\mathrm{H}_{2}$ evolution reaction (HER). While various metal surfaces (bulk foils) have been identified to efficiently reduce $\mathrm{CO}_{2}$ into value-added carbon-based products such as $\mathrm{CO}(\mathrm{Au}, \mathrm{Ag}$, and $\mathrm{Zn}$ ), formic acid ( $\mathrm{Sn}, \mathrm{In}$, and $\mathrm{Bi}$ ), and hydrocarbons $(\mathrm{Cu}){ }^{3}$ their catalytic activity, selectivity, and stability are still insufficient for industrial acceptance. In order to enhance the performance of metal catalysts, several strategies have been proposed, including nanostructuring the metals, ${ }^{4-11}$ engineering the metal/electrolyte interface, ${ }^{12-17}$ or introducing a secondary metal to create bimetallic structural motifs. ${ }^{18-27}$

The utilization of bimetallic catalysts has been considered a promising approach to obtain improved catalytic performance for $\mathrm{CO}_{2} \mathrm{RR}^{28,29} \mathrm{CuZn}$ is of particular interest due to its low cost and lack of toxicity. Recent studies have demonstrated enhanced reactivity of $\mathrm{CuZn}$ catalysts for $\mathrm{CO}_{2} \mathrm{RR}^{30-36}$ For example, nanoporous $\mathrm{CuZn}$ catalysts prepared by annealing and subsequent reduction of commercial $\mathrm{CuZn}$ alloy foils showed four and six times higher Faradaic efficiency (F.E.) for $\mathrm{CO}$ and $\mathrm{HCOOH}$ than those of the untreated $\mathrm{CuZn}$ foils. ${ }^{32}$ $\mathrm{Zn}$-coated $\mathrm{Cu}$ electrodes exhibited higher selectivity for $\mathrm{CH}_{4}$ (52\% F.E.) than bare $\mathrm{Cu}\left(23 \% \mathrm{FE}\right.$ for $\left.\mathrm{CH}_{4}\right){ }^{33}$ Oxide-derived $\mathrm{CuZn}$ catalysts were favorable toward the formation of $\mathrm{C}_{2}$ products (i.e., $\mathrm{C}_{2} \mathrm{H}_{4}$ and $\mathrm{C}_{2} \mathrm{H}_{5} \mathrm{OH}$ ), and it was possible to tune the ratio of these products by varying the amount of $\mathrm{Zn}^{34}$ This trend in the $\mathrm{C}_{2}$ selectivity was postulated to be due to the spillover of $\mathrm{CO}$ from $\mathrm{Zn}$ to $\mathrm{Cu}$ sites, which was thought to facilitate the production of $\mathrm{C}_{2}$ products at the $\mathrm{Cu}$ site. ${ }^{34}$ Such $\mathrm{CO}$ spillover effects were found to be facilitated when a homogeneous distribution of $\mathrm{Cu}$ and $\mathrm{Zn}$ atoms was formed in the CuZn catalysts. ${ }^{35}$

However, despite the former encouraging empirical results, significant discrepancies in the product selectivity of seemingly similar CuZn systems have been reported, and fundamental

Received: October 4, 2019

Published: November 24, 2019 

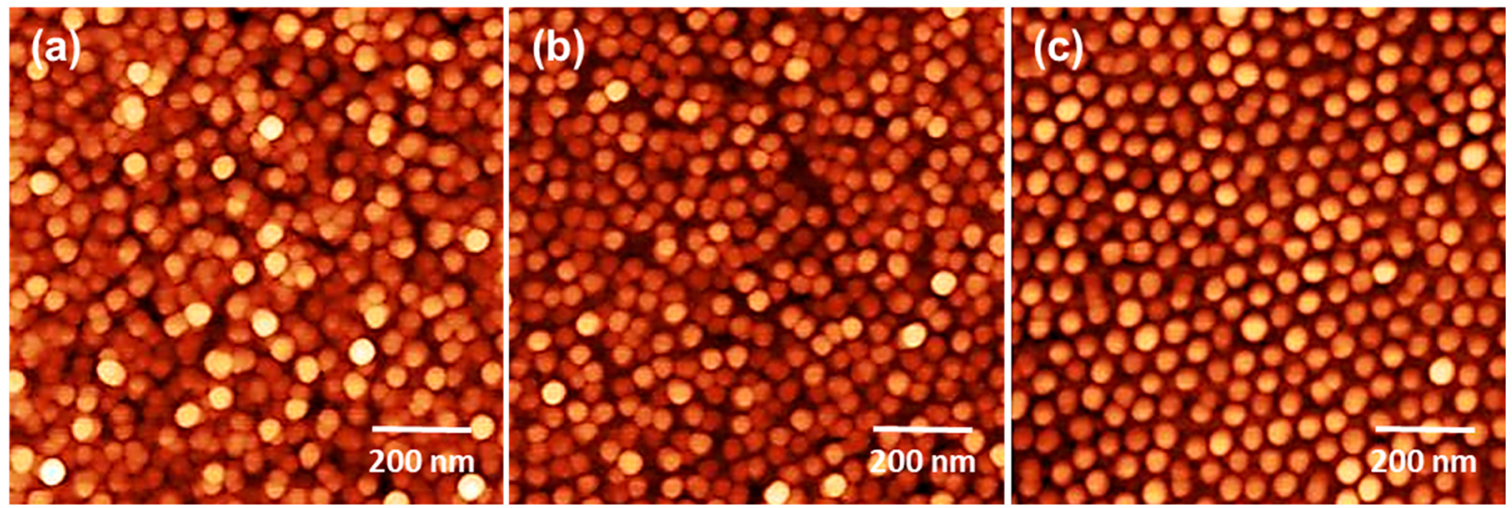

Figure 1. AFM images of $\mathrm{Cu}_{100-x} \mathrm{Zn}_{x}$ NPs supported on $\mathrm{SiO}_{2} / \mathrm{Si}(111)$. (a) $\mathrm{Cu}_{100}$, (b) $\mathrm{Cu}_{50} \mathrm{Zn}_{50}$, and (c) $\mathrm{Zn}_{100}$.

understanding is still missing regarding the reaction pathways, catalyst structure, and composition leading to a given selectivity trend. Moreover, uncertainties remain concerning the relative importance of the different parameters that may be adjusted in order to tune the materials electrocatalytic performance. For the bulk $\mathrm{CuZn}$ catalysts previously investigated, grain boundaries, ${ }^{37-39}$ local $\mathrm{pH}$ effects, ${ }^{40-42}$ or the presence of cationic metal species ${ }^{6,43-46}$ have been suggested to contribute to their altered product selectivity. However, the complexity of these material systems hinders our ability to disentangle the specific role of different parameters, which is required in order to understand the intrinsic reactivity of the $\mathrm{CuZn}$ system for $\mathrm{CO}_{2} \mathrm{RR}$.

In this work, morphologically and chemically well-defined $\sim 5 \mathrm{~nm} \mathrm{CuZn}$ nanoparticles (NPs) were synthesized via inverse micelle encapsulation and used to investigate the correlation between their structure, composition, and electrocatalytic activity and selectivity. By means of quasi in situ X-ray photoelectron spectroscopy (XPS) and operando X-ray absorption fine-structure spectroscopy (XAFS), the evolution of the structure, chemical state, and composition of the $\mathrm{CuZn}$ NPs was investigated under working $\mathrm{CO}_{2} \mathrm{RR}$ conditions. The gradual formation of a $\mathrm{Cu}-\mathrm{Zn}$ alloy could be observed in the course of the $\mathrm{CO}_{2} \mathrm{RR}$ and correlated to the switch in selectivity from $\mathrm{CH}_{4}$ to $\mathrm{CO}$.

\section{EXPERIMENTAL SECTION}

2.1. Preparation of CuZn NPs. Bimetallic CuZn nanoparticles (NPs) with the same nominal NP size but variable composition were prepared by an inverse micelle encapsulation method. ${ }^{47}$ The elemental composition was modified by controlling the molar ratio of the $\mathrm{Cu}$ and $\mathrm{Zn}$ precursor salts. $\mathrm{CuCl}_{2}$ and $\mathrm{Zn}\left(\mathrm{CH}_{3} \mathrm{COO}\right)_{2}$ were dissolved in a solution of toluene and tetrahydrofuran, followed by the addition of a second toluene solution with a poly(styrene)-blockpoly(2-vinylpyridine) diblock copolymer (PS(48500)-P2VP(70000), Polymer Source, Inc.). The mixture was then stirred for 2 days. The encapsulated CuZn NPs were deposited on glassy carbon substrates. After deposition, an $\mathrm{O}_{2}$-plasma etch treatment $(20 \mathrm{~W}$ for $10 \mathrm{~min}$, $\sim 400$ mTorr $\mathrm{O}_{2}$ ) was used to remove the polymeric ligands. The specific synthesis parameters of the seven samples used in this study can be found in Table S1.

2.2. Morphological Characterization. Atomic force microscopy (AFM, Bruker, Multimode 8) was used to determine the NP height $\left(h_{\mathrm{p}}\right)$. The CuZn NPs were deposited on silicon wafers for more accurate measurement of $h_{\mathrm{p}}$, since the glassy carbon electrode used for the electrochemical measurements has a rougher surface that makes difficult the background subtraction needed for the NP height determination. The average NP height was used to calculate the average CuZn geometric surface area of the NPs, $A_{\mathrm{CuZn}}=4 \pi\left(h_{\mathrm{p}} / 2\right)^{2}$, assuming spherical micellar NPs. The metal NP surface area was then multiplied by the NP number density to estimate the total surface area of the CuZn NPs in each sample. This parameter was used for the normalization of the current data.

2.3. Electrochemical Characterization. Electrochemical $\mathrm{CO}_{2}$ reduction experiments were conducted using an Autolab potentiostat (Multi Autolab M204) in an H-type two-compartment electrochemical cell made of polyether ether ketone (PEEK) separated by an anion-exchange membrane (Selemion AMV). A platinum mesh counter electrode and a leak-free $\mathrm{Ag} / \mathrm{AgCl}$ reference electrode (Innovative Instruments) were used in a three electrode configuration. Purified $0.1 \mathrm{M} \mathrm{KHCO}_{3}$ solutions were prepared by treating the electrolyte with Chelex 100 Resin (Bio-Rad). The electrolyte was saturated with $\mathrm{CO}_{2}$ until a $\mathrm{pH}$ of 6.8 was achieved. Each data point presented corresponds to an identical freshly prepared sample measured with the chronoamperometric technique at $-1.35 \mathrm{~V}$ versus RHE.

The gas products were quantified by gas chromatography (GC, Agilent 7890B) equipped with thermal conductivity (TCD) and flame ionization (FID) detectors. The GC was directly connected to the electrochemical cell for online gas analysis. $\mathrm{CO}_{2}$ gas was bubbled through the electrolyte at an average rate of $20 \mathrm{~mL} \mathrm{~min}^{-1}$. The formic acid concentration was analyzed by high-performance liquid chromatography (HPLC, Shimadzu Prominence) equipped with a NUCLEOGEL SUGAR 810 column and a refractive index detector (RID).

2.4. Structural and Chemical Characterization. Quasi in situ X-ray photoelectron spectroscopy (XPS) measurements were performed in an ultrahigh-vacuum setup equipped with a nonmonochromatic $\mathrm{Al} \mathrm{X}$-ray source $(h v=1486.6 \mathrm{eV})$ and a hemispherical electron analyzer (Phoibos 100, SPECS GMbH). The XPS analysis chamber was connected to an electrochemical cell allowing sample transfer without exposure to air after electrochemistry. The measurements were conducted using an analyzer pass energy of $E_{\text {pass }}=$ $13 \mathrm{eV}$ and a source power of $P=300 \mathrm{~W}$. All spectra were aligned to the carbon peak $\left(E_{\mathrm{bin}}=284.8 \mathrm{eV}\right)$ of the glassy carbon substrate. The composition ratio of $\mathrm{Cu}$ to $\mathrm{Zn}$ was calculated taking into account the relative sensitivity factors $(\mathrm{RSF})$ of the metals $\left(\mathrm{Cu} \mathrm{2} \mathrm{p}_{3 / 2}: 20.28 ; \mathrm{Zn}\right.$ $\left.2 \mathrm{p}_{3 / 2}: 23.93\right)$ for an angle of $54^{\circ}$ between the $\mathrm{X}$-ray source and the analyzer and the transmission function of the analyzer.

Operando X-ray absorption fine-structure spectroscopy (XAFS) measurements were performed at the SAMBA beamline at SOLEIL synchrotron (France). A homemade electrochemical cell was used to acquire the XAFS spectra. All samples were measured in air and under operando conditions, while the potential was kept constant at $-1.35 \mathrm{~V}$ versus RHE in a $\mathrm{CO}_{2}$-saturated $0.1 \mathrm{M} \mathrm{KHCO}_{3}$ electrolyte. XAFS spectra for the $\mathrm{Cu}$ K-edge $\left(E_{0}=8979 \mathrm{eV}\right)$ and $\mathrm{Zn} \mathrm{K}$-edge $\left(E_{0}=9659\right.$ $\mathrm{eV}$ ) were collected separately. Identically prepared (same NP solution) but different (fresh) samples were used for measurements at either the $\mathrm{Cu}$ or the $\mathrm{Zn}$ absorption edges. Further details of the XAFS measurements are given in the Supporting Information. Under $\mathrm{CO}_{2} \mathrm{RR}$ conditions, multiple XAFS spectra were acquired, until there 
were no visible changes. This took several hours for these samples. Here we use time-dependent X-ray absorption near edge structure (XANES) data to follow the evolution of the sample structure and composition. We also analyzed extended X-ray absorption fine structure (EXAFS) data and compared the data obtained for samples in their as-prepared state in air and in their final state after several hours under applied potential. In addition to the evaluation of the XANES data, EXAFS spectra collected after $1 \mathrm{~h} \mathrm{CO}_{2} \mathrm{RR}$ under potential were also analyzed. Note, however, that the acquisition of a single EXAFS spectrum took ca. $12 \mathrm{~min}$, which limits our time resolution. Moreover, due to the low signal-to-noise ratio, analysis of individual EXAFS spectra is problematic, and several spectra needed to be merged. Therefore, the representative EXAFS spectrum for a sample after $1 \mathrm{~h}$ of $\mathrm{CO}_{2} \mathrm{RR}$ was obtained after merging 4 spectra collected during 40-80 min of $\mathrm{CO}_{2} \mathrm{RR}$.

Alignment, background subtraction, and normalization of the XAFS spectra were performed using the conventional approach as implemented in the Athena software. ${ }^{48}$ Linear combination fitting was used to process the XANES data. To obtain quantitative information about the distributions of bond lengths, we performed $\mathrm{Cu}-$ and $\mathrm{Zn} \mathrm{K}$-edge EXAFS data fitting. Details of EXAFS data fitting are given in the Supporting Information.

\section{RESULTS AND DISCUSSION}

Figures 1 and S1 present AFM images of CuZn NPs with variable composition ratios. The AFM images show that all NPs exhibit spherical shape with uniform coverage across the substrate and narrow size distribution, with an average size of ca. $5 \mathrm{~nm}$. Figure S2 displays the NP height histograms and the average values are included in Table S1. Following our previous work, ${ }^{46}$ the metal NP coverage was chosen to be large enough (Table S1) so that the interparticle reactant diffusion and probability of readsorption of intermediates is not hindered.

In order to investigate the surface composition and chemical state of the CuZn NPs in their as-prepared state and after $\mathrm{CO}_{2} \mathrm{RR}$, quasi in situ XPS measurements were carried out. Figures 2 and S3 show the XPS spectra of the CuZn NPs in their as-prepared state and after $\mathrm{CO}_{2} \mathrm{RR}$. The surface composition ratio was obtained by integrating the areas of the $\mathrm{Cu} 2 \mathrm{p}_{3 / 2}$ and $\mathrm{Zn} 2 \mathrm{p}_{3 / 2}$ spectra. It was confirmed that the composition of the as-prepared samples was consistent with the starting molar ratio of the precursor salts, and that it did not change after the $\mathrm{CO}_{2} \mathrm{RR}$ (Figure S4).

As shown in Figure 2a, $\mathrm{Cu}$ in the as-prepared samples after $\mathrm{O}_{2}$-plasma treatment was found to be in $\mathrm{Cu}^{2+}$ state, as evidenced by the shakeup satellites. ${ }^{47,49}$ After $1 \mathrm{~h} \mathrm{CO} \mathrm{CO}_{2} \mathrm{RR}$, the shakeup features vanished. Simultaneously, a shift of the $\mathrm{Cu}$ $2 \mathrm{p}_{3 / 2}$ main peak toward lower binding energies was observed $(\Delta E=1.0 \mathrm{eV})$. Nevertheless, a $\sim 0.8 \mathrm{eV}$ higher binding energy than that of bulk metallic $\mathrm{Cu}$ was observed after $\mathrm{CO}_{2} \mathrm{RR}$. This binding energy shift can be attributed to the initial and final state effects typically observed for small NPs. ${ }^{49}$ We also attempted to detect the presence of $\mathrm{Cu}^{+}$species and distinguish them from $\mathrm{Cu}$ metal by using the $\mathrm{Cu}$ LMM Auger peak. ${ }^{50}$ Unfortunately, the former signal for our lowmetal coverage NP samples was beyond the detection limit. The $\mathrm{Zn} 2 \mathrm{p}$ region (Figures $2 \mathrm{~b}$ and $\mathrm{S} 3$ ) shows that before $\mathrm{CO}_{2} \mathrm{RR}$ the NPs are in the $\mathrm{Zn}^{2+}$ state $(\mathrm{ZnO})$. The small change of $0.5 \mathrm{eV}$ toward higher binding energies of the $\mathrm{Zn}$ $2 \mathrm{p}_{3 / 2}$ peak obtained after $1 \mathrm{~h} \mathrm{CO} \mathrm{CO}_{2} \mathrm{RR}$ is attributed to the presence of $\mathrm{Zn}(\mathrm{OH})_{2}$. ${ }^{51}$

Figure 3 shows the current density and F.E. for the CuZn NP samples as a function of their composition. As shown in Figure $3 \mathrm{a}$, the $\mathrm{Cu}_{100}$ NPs exhibit the highest activity among all
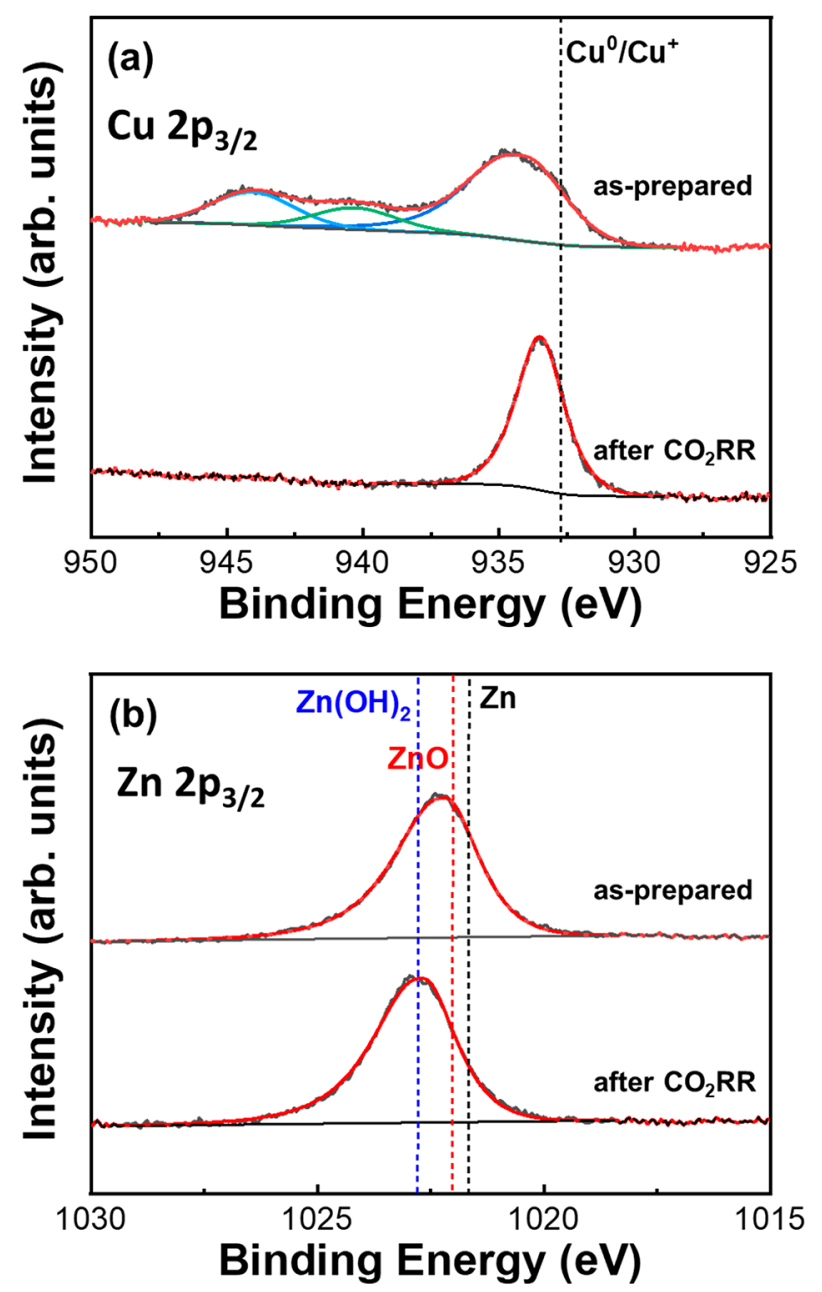

Figure 2. Quasi in situ XPS spectra of the (a) Cu $2 p_{3 / 2}$ and (b) $\mathrm{Zn}$ $2 \mathrm{p}_{3 / 2}$ core level regions of $\mathrm{Cu}_{50} \mathrm{Zn}_{50}$ NPs deposited on glassy carbon acquired before and after (without air exposure) $1 \mathrm{~h}$ of $\mathrm{CO}_{2} \mathrm{RR}$ at $-1.35 \mathrm{~V}$ vs RHE.

investigated samples, and the activity was found to monotonically decrease with increasing $\mathrm{Zn}$ content in the CuZn NPs. Interestingly, the F.E. of the CuZn NPs showed different selectivity during $\mathrm{CO}_{2} \mathrm{RR}$ depending on the $\mathrm{Cu}$ to $\mathrm{Zn}$ ratio (Figure $3 \mathrm{~b}$ ). $\mathrm{Cu}_{100}$ and $\mathrm{Zn}_{100}$ NPs produced $\mathrm{CH}_{4}$ and $\mathrm{CO}$ as the main products, respectively. The three $\mathrm{Cu}_{100-x} \mathrm{Zn}_{x}$ NPs $(x$ $=10,30$, and 50) exhibited enhanced $\mathrm{CH}_{4}$ F.E. compared to pure $\mathrm{Cu}$ NPs. Nonetheless, the increased $\mathrm{CH}_{4}$ selectivity of these three samples was abruptly suppressed when the $\mathrm{Zn}$ content was higher than $70 \%$, whereas CO selectivity was found to increase.

In order to further understand the reactivity of the $\mathrm{CuZn}$ NPs for $\mathrm{CO}_{2} \mathrm{RR}$, we also compared the partial current density of the major products as a function of the NP composition, as shown in Figure S5. Interestingly, we found that $\mathrm{H}_{2}$ production showed a different trend depending on the $\mathrm{CH}_{4}$ and $\mathrm{CO}$ production of the $\mathrm{CuZn}$ NPs. The $\mathrm{H}_{2}$ production was significantly suppressed upon increasing the $\mathrm{Zn}$ concentration for the $\mathrm{Cu}$-rich $\mathrm{CH}_{4}$-producing $\mathrm{CuZn} \mathrm{NPs} \mathrm{(i.e.,} \mathrm{Cu}_{90} \mathrm{Zn}_{10}$, $\mathrm{Cu}_{70} \mathrm{Zn}_{30}$, and $\mathrm{Cu}_{50} \mathrm{Zn}_{50}$ ), while no changes in $\mathrm{H}_{2}$ with $\mathrm{Zn}$ concentration were observed when the $\mathrm{Zn}$-rich $\mathrm{CO}$-producing $\mathrm{CuZn}$ NPs (i.e., $\mathrm{Cu}_{30} \mathrm{Zn}_{70}$ and $\mathrm{Cu}_{10} \mathrm{Zn}_{90}$ ) were considered. This result suggests that the protons that should be used to 

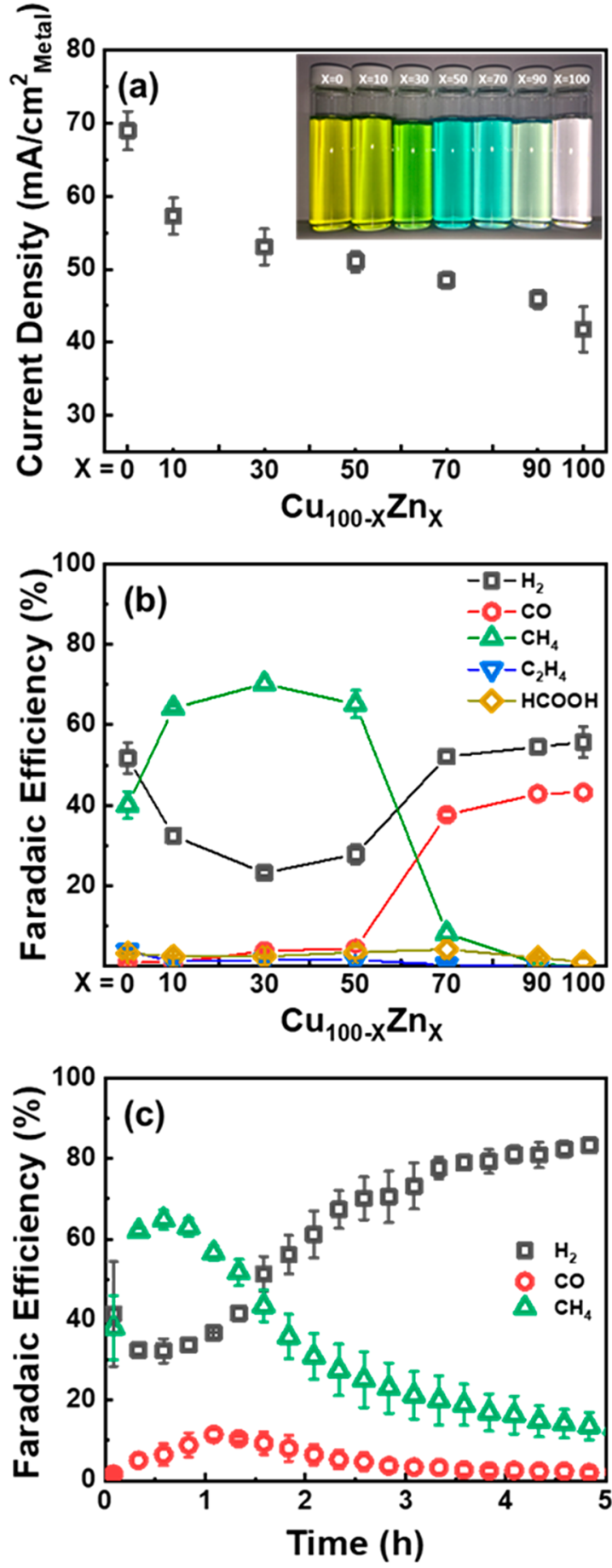

Figure 3. Activity and selectivity measurements of $\mathrm{CO}_{2} \mathrm{RR}$ over $\mathrm{Cu}_{100-x} \mathrm{Zn}_{x}$ NPs. (a) Geometric current density and (b) Faradaic efficiency toward $\mathrm{H}_{2}, \mathrm{CO}, \mathrm{CH}_{4}, \mathrm{C}_{2} \mathrm{H}_{4}$, and $\mathrm{HCOOH}$ measured during $1 \mathrm{~h}$ of electrolysis at $-1.35 \mathrm{~V}$ vs RHE in $0.1 \mathrm{M} \mathrm{KHCO}_{3}$ as a function of the NP composition. (c) Stability test of $\mathrm{Cu}_{50} \mathrm{Zn}_{50}$ NPs for the main products of $\mathrm{CO}_{2} \mathrm{RR}$ at $-1.35 \mathrm{~V}$ vs RHE as a function of time. The insert in (a) shows a photograph of the vials with the different CuZn NP solutions.

generate $\mathrm{H}_{2}$ from water splitting have now a more favorable pathway toward $\mathrm{CH}_{4}$ formation in the $\mathrm{Cu}$-rich NPs.

In general, the product selectivity of $\mathrm{CO}_{2}$ reduction is determined by the binding strength of adsorbed $* \mathrm{CO}$ and ${ }^{*} \mathrm{H}$ on the metal surface. ${ }^{52,53}$ According to previous studies, since a bulk polycrystalline $\mathrm{Cu}$ electrode has a moderate binding energy for adsorbed $* \mathrm{CO}$, such $* \mathrm{CO}$ species can be further hydrogenated to produce $\mathrm{CH}_{4}{ }^{54-56}$ On the other hand, a relatively weak binding strength of adsorbed $* \mathrm{CO}$ is known for polycrystalline $\mathrm{Zn}$ electrodes, leading to $\mathrm{CO}$ production without further reaction. ${ }^{34,35}$ These are also the main products detected for our monometallic $\mathrm{Cu}_{100}$ and $\mathrm{Zn}_{100} \mathrm{NP}$ samples. However, it should be also considered that the enhanced fraction of low-coordinated atoms in NP samples such as those available here $(5 \mathrm{~nm})$ affect the relative binding of $* \mathrm{H}$ and *CO with respect to bulk systems of analogous composition, leading to distinct selectivity trends, in particular, enhanced $\mathrm{H}_{2}$ production, as previously reported. ${ }^{47,51}$ Interestingly, we found for our CuZn NPs increased $\mathrm{CH}_{4}$ production as compared to $\mathrm{Cu}_{100}$ NPs. However, when the $\mathrm{Zn}$ content was higher than $70 \%$ in the bimetallic NPs, only $\mathrm{CO}$ and $\mathrm{H}_{2}$ were produced. In the latter case, the proton and adsorbed $* \mathrm{CO}$ species that were not participating in the hydrogenation with adsorbed $* \mathrm{CO}$ on the $\mathrm{Cu}$ site may be released as $\mathrm{H}_{2}$ and $\mathrm{CO}$. Furthermore, the stability tests of the $\mathrm{Cu}_{50} \mathrm{Zn}_{50}$ sample showed that the enhanced $\mathrm{CH}_{4}$ selectivity started to drop after $1 \mathrm{~h}$, which is accompanied by a slight increase in CO selectivity (Figure 3c). This result indicates that the functionality of the $\mathrm{Cu}$ sites has changed over time.

To gain more detailed information about the chemical state and structure of the electrocatalysts during $\mathrm{CO}_{2} \mathrm{RR}$, XAFS measurements were conducted under operando conditions. Figure 4 shows selected $\mathrm{Cu}$ and $\mathrm{Zn} \mathrm{K}$-edge XANES spectra for $\mathrm{Cu}_{50} \mathrm{Z}_{50} \mathrm{NPs}$ in their as-prepared state and under $\mathrm{CO}_{2} \mathrm{RR}$ conditions. Similar plots for $\mathrm{Cu}_{30} \mathrm{Zn}_{70}$ and $\mathrm{Zn}_{100}$ samples are given in Figure S6. Complete sets of time-dependent XANES spectra for these samples are shown in Figure S7. The position of the absorption edge in the XANES spectra of the asprepared samples and the direct comparison with the reference materials (Figure 4 and S8) indicate that the $\mathrm{Cu}$ and $\mathrm{Zn}$ components are initially completely oxidized and predominantly in the $2+$ oxidation state. The local structure around the $\mathrm{Cu}$ atoms is similar to that in $\mathrm{Cu}(\mathrm{OH})_{2}$, while from the $\mathrm{Zn}$ $K$-edge data we could not assign the observed XANES features to any particular reference material and can only conclude that some disordered oxide (or hydroxide) structure is formed. ${ }^{51}$

Under $\mathrm{CO}_{2} \mathrm{RR}$ conditions, both $\mathrm{Cu}$ and $\mathrm{Zn}$ are reduced, as evidenced by the observed changes in the $\mathrm{Cu}$ and $\mathrm{Zn} \mathrm{K}$-edge XANES spectra, which become more similar to those of $\mathrm{Cu}$ and $\mathrm{Zn}$ foils (Figures 4 and S6-S7). Interestingly, the reduction rates appear to be very different for $\mathrm{Cu}$ and $\mathrm{Zn}$. We observed that the $\mathrm{Cu} K$-edge XANES spectra did not change much after the prompt initial reduction during the first scan under applied potential. However, at the $\mathrm{Zn} \mathrm{K}$-edge some variations in the XANES spectra for samples under potential were observed that had significantly longer characteristic times. To quantify these trends, we performed linear combination analysis using as reference the corresponding XANES spectra of the as-prepared sample (spectrum A in Figures 4a,b and S6), and the final spectrum (spectrum $\mathrm{C}$ in Figures $4 a, b$ and S6) obtained after several hours under $\mathrm{CO}_{2} \mathrm{RR}$ conditions. The results for different samples and absorption edges are compared in Figure 4c. It is evident that the reduction of $\mathrm{ZnO}$ species takes several hours, while that of the $\mathrm{Cu}$ oxide species is completed during the first XAFS scan within several minutes. In agreement with the quasi in situ XPS results, neither the $\mathrm{Zn}$ on the NP surface nor that inside the NP core is completely reduced after $1 \mathrm{~h}$ of $\mathrm{CO}_{2} \mathrm{RR}$. The reduction rate of $\mathrm{Zn}$ depends, however, on the $\mathrm{Cu}_{100-x} \mathrm{Zn}_{x}$ composition, with 

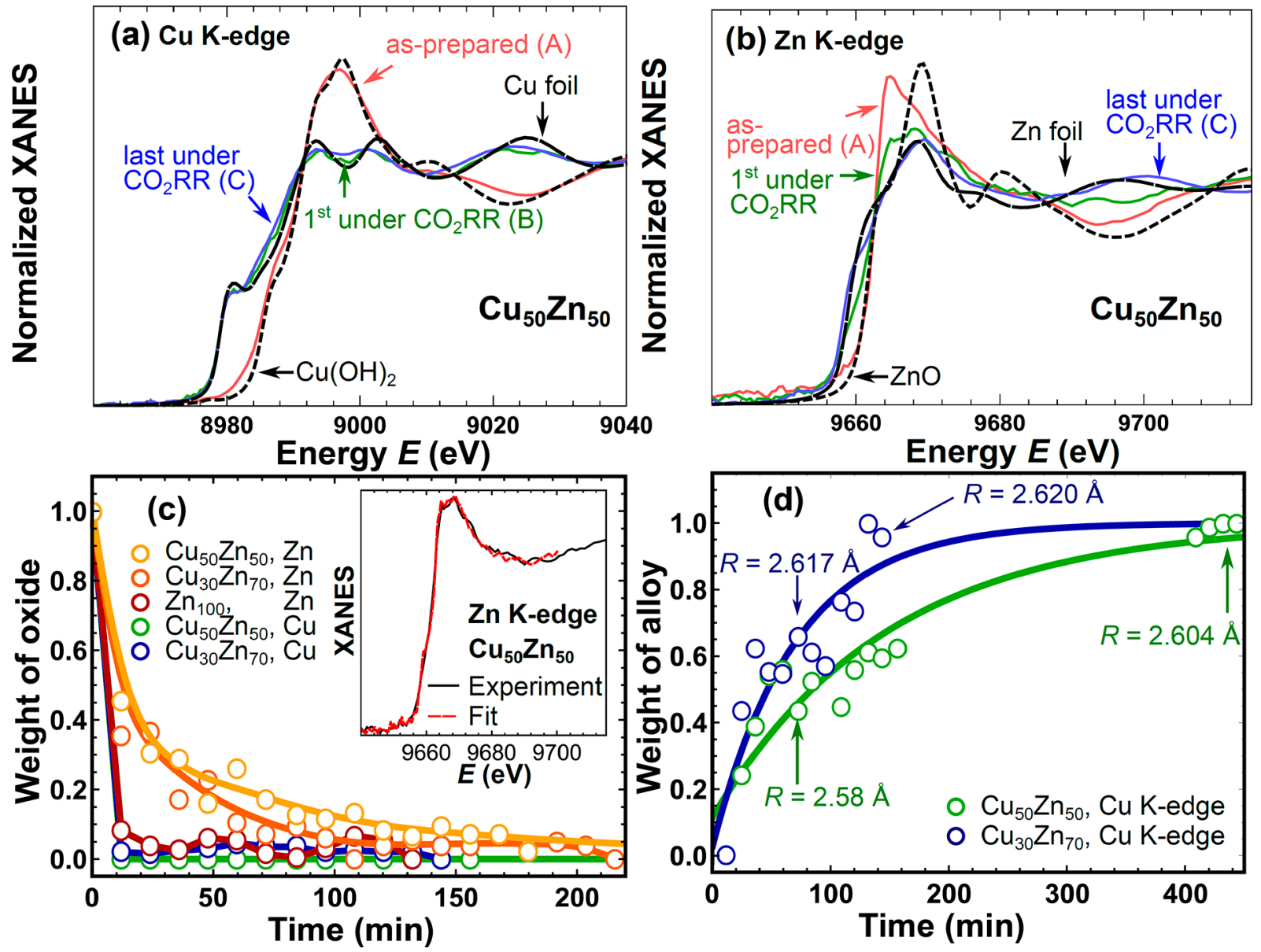

Figure 4. Selected (a) $\mathrm{Cu} K$-edge and (b) $\mathrm{Zn} \mathrm{K}$-edge XANES spectra of $\mathrm{Cu}_{50} \mathrm{Zn}_{50}$ NPs corresponding to as-prepared oxidized samples (spectrum A), samples immediately after the onset of $\mathrm{CO}_{2} \mathrm{RR}$ conditions (spectrum $\mathrm{B}$ ) and the final spectrum collected after $7 \mathrm{~h}$ under $\mathrm{CO}_{2} \mathrm{RR}$ conditions (spectrum C). (c) Linear combination analysis results for the $\mathrm{Zn} \mathrm{K}$-edge and $\mathrm{Cu} K$-edge of XANES data of $\mathrm{Cu}_{50} \mathrm{Zn}_{50}$ and $\mathrm{Cu}_{30} \mathrm{Zn}_{70} \mathrm{NPs}$ obtained using spectrum A (oxidized sample) and spectrum $C$ (completely reduced sample) as reference. The inset shows a representative linear combination fit (result for $\mathrm{Zn} \mathrm{K}$-edge spectrum of $\mathrm{Cu}_{50} \mathrm{Zn}_{50}$ NPs immediately after the onset of $\mathrm{CO}_{2} \mathrm{RR}$ conditions). (d) Linear combination analysis results of $\mathrm{Cu} \mathrm{K}$-edge XANES data using spectra $\mathrm{B}$ and $\mathrm{C}$ as reference, where the latter corresponds to the most alloyed state. $\mathrm{Cu}-\mathrm{M}$ interatomic distances, as extracted from EXAFS data fitting, are also shown. Solid lines are guides for the eye.
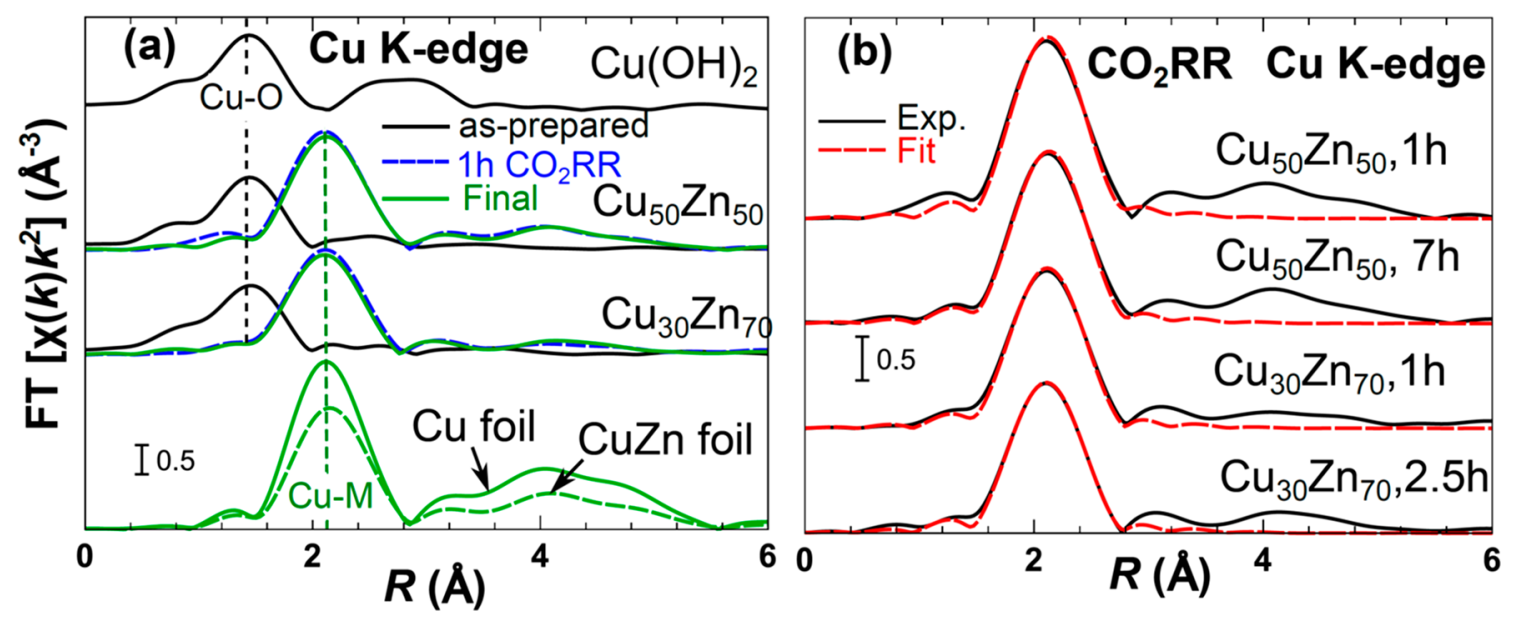

Figure 5. Fourier-transformed (FT) $k^{2}$-weighted $\mathrm{Cu} K$-edge EXAFS data for $\mathrm{Cu}_{50} \mathrm{Zn}_{50}$ and $\mathrm{Cu}_{30} \mathrm{Zn}_{70} \mathrm{NPs}$ measured (a) as-prepared in air, after $1 \mathrm{~h}$ of $\mathrm{CO}_{2} \mathrm{RR}$ (dashed line) and in the final state (solid line). (b) EXAFS fitting results for $\mathrm{Cu}_{50} \mathrm{Zn}_{50}$ and $\mathrm{Cu}_{30} \mathrm{Zn}_{70} \mathrm{NPs}$ under $\mathrm{CO}_{2} \mathrm{RR}$ for the different times indicated. Reference spectra from a $\mathrm{Cu}$ foil, $\mathrm{CuZn}$ foil, and $\mathrm{Cu}(\mathrm{OH})_{2}$ are also shown for comparison.

$\mathrm{ZnO}$ species in pure $\mathrm{Zn} \mathrm{NPs} \mathrm{becoming} \mathrm{reduced} \mathrm{significantly}$ faster than those in the bimetallic CuZn NPs. Since the $\mathrm{Cu}$ oxide species initially present in the small $(\sim 5 \mathrm{~nm})$ NPs were found by XAFS to become reduced very promptly (within several minutes), they can be ruled out as responsible for the much slower change in the selectivity observed. 
Even though the chemical state of the $\mathrm{Cu}$ species was stable (reduced) during the reaction, small variations in the $\mathrm{Cu} \mathrm{K}$ edge XANES spectra can still be observed, which can be linked to gradual changes in the local structure around $\mathrm{Cu}$. To track these changes, linear combination analysis is employed, using in this case as references $\mathrm{Cu} K$-edge XANES spectra corresponding to the final state (spectrum $\mathrm{C}$ in Figures $4 \mathrm{a}$ and $\mathrm{S} 6 \mathrm{~b}$ ) and the first $\mathrm{Cu} \mathrm{K}$-edge XANES spectrum for a reduced sample (obtained after several minutes under $\mathrm{CO}_{2} \mathrm{RR}$ conditions, spectrum B in Figures $4 \mathrm{a}$ and $\mathrm{S} 6 \mathrm{~b}$ ). The obtained results, Figure $4 \mathrm{~d}$, demonstrate that the local structure around the $\mathrm{Cu}$ atoms continues evolving even after $\mathrm{Cu}$ is completely reduced. It should be noted that the characteristic times at which changes in the $\mathrm{Cu}$ K-edge XANES spectra are observed (Figure $4 \mathrm{~d}$ ) correlate well with the characteristic times of the reduction of the cationic $\mathrm{Zn}$ species (Figure 4c). Thus, from this observation, we can infer that the changes observed originate from the gradual enrichment of the samples with reduced $\mathrm{Zn}$ species and the interaction between the metallic $\mathrm{Cu}$ and metallic $\mathrm{Zn}$ species formed during $\mathrm{CO}_{2} \mathrm{RR}$.

To better understand the nature of the $\mathrm{Cu}-\mathrm{Zn}$ interactions, EXAFS spectra, which are more sensitive to the geometry of the environment around the absorbing atoms, were analyzed. Fourier transformed (FT) $\mathrm{Cu} K$-edge EXAFS spectra of $\mathrm{Cu}_{50} \mathrm{Zn}_{50}, \mathrm{Cu}_{30} \mathrm{Zn}_{70}$, and $\mathrm{Zn}_{100}$ NPs measured for the asprepared samples, for samples after $1 \mathrm{~h}$ of $\mathrm{CO}_{2} \mathrm{RR}$ and in the final state (after $7 \mathrm{~h}, 2.5 \mathrm{~h}$, and $2 \mathrm{~h}$ of $\mathrm{CO}_{2} \mathrm{RR}$ for $\mathrm{Cu}_{50} \mathrm{Zn}_{50}$, $\mathrm{Cu}_{30} \mathrm{Zn}_{70}$, and $\mathrm{Zn}_{100} \mathrm{NPs}$, correspondingly) are shown in Figure 5a (Cu-K-edge) and Figure S8a (Zn-K-edge). In agreement with the XANES data analysis, the FT-EXAFS spectra of the as-prepared samples reveal the presence of $\mathrm{M}-\mathrm{O}$ $(\mathrm{M}=\mathrm{Cu}$ and $\mathrm{Zn})$ structural motifs, as evidenced by a strong peak at ca. $1.5 \AA$ (phase uncorrected). Overall, the FT-EXAFS spectra for the $\mathrm{Cu} K$-edge in the as-prepared samples are close to those of $\mathrm{Cu}(\mathrm{OH})_{2}$.

Under $\mathrm{CO}_{2} \mathrm{RR}$ conditions, the $\mathrm{M}-\mathrm{O}$ peak disappears completely in the $\mathrm{Cu} \mathrm{K}$-edge data, while a strong peak at ca. 2.1-2.2 A appears, which can be associated with the presence of $\mathrm{M}-\mathrm{M}$ bonds. Thus, complete reduction of cationic $\mathrm{Cu}$ species in all $\mathrm{CuZn}$ samples is observed, in agreement with XANES data. Note here that since $\mathrm{Cu}$ and $\mathrm{Zn}$ are neighbors in the Periodic Table we cannot easily distinguish between $\mathrm{Cu}-$ $\mathrm{Zn}$ and $\mathrm{Cu}-\mathrm{Cu}$ (or $\mathrm{Zn}-\mathrm{Zn}$ and $\mathrm{Zn}-\mathrm{Cu}$ ) contributions. By comparing spectra obtained after $1 \mathrm{~h}$ of $\mathrm{CO}_{2} \mathrm{RR}$ with the final spectra obtained after several hours of $\mathrm{CO}_{2} \mathrm{RR}$, small variations can be observed (more pronounced in the $\mathrm{Zn} \mathrm{K}$-edge data, Figure S9a), suggesting some gradual structural changes not only in the $\mathrm{Zn}$ but also in the $\mathrm{Cu}$ atomic environment.

For quantitative analysis, EXAFS data fitting was performed. For samples under $\mathrm{CO}_{2} \mathrm{RR}$ conditions, $\mathrm{Cu} \mathrm{K}$-edge EXAFS fitting results are summarized in Figure $5 \mathrm{~b}$ and in Table S2. The fitting results of the $\mathrm{Cu}$ and $\mathrm{Zn} \mathrm{K}$-edge EXAFS data of the as-prepared samples are presented in the Figure $\mathrm{S} 9 \mathrm{~b}-\mathrm{d}$ and Tables S3 and S4. The main finding from the $\mathrm{Cu} \mathrm{K}$-edge EXAFS data analysis is that the $\mathrm{Cu}-\mathrm{M}$ interatomic distance is different in $\mathrm{Cu}_{50} \mathrm{Zn}_{50}\left(2.58 \pm 0.01 \AA\right.$ after $1 \mathrm{~h}$ under $\mathrm{CO}_{2} \mathrm{RR}$ conditions) as compared to the $\mathrm{Cu}_{30} \mathrm{Zn}_{70}(2.617 \pm 0.008 \AA)$ NP sample (Table S2 and Figure $5 \mathrm{~b}$ ). Both distances are in between those of a $\mathrm{Cu}$ foil $(2.56 \AA)$ and a brass $\mathrm{CuZn}$ foil $(2.62 \AA)$, suggesting alloying of $\mathrm{Cu}$ with $\mathrm{Zn}$. The increase of the interatomic distances in fcc-type $\mathrm{Cu}-\mathrm{Zn}$ alloys with increasing $\mathrm{Zn}$ concentration is in agreement with $\mathrm{X}$-ray diffraction data. ${ }^{57}$ Moreover, the interatomic distances change with time. Table S2 provides the values of the fitting variables obtained for the $\mathrm{Cu}_{30} \mathrm{Zn}_{70}$ NPs after $2.5 \mathrm{~h} \mathrm{CO} \mathrm{CO}_{2} \mathrm{RR}$ and for $\mathrm{Cu}_{50} \mathrm{Zn}_{50}$ NPS after $7 \mathrm{~h}$. For both samples we observed an increase of the $\mathrm{Cu}-\mathrm{M}$ distance with time, reaching $2.620 \pm$ $0.008 \AA$ for $\mathrm{Cu}_{30} \mathrm{Zn}_{70}$ NPs and $2.604 \pm 0.008 \AA$ for $\mathrm{Cu}_{50} \mathrm{Zn}_{50}$ NPs. In both cases the interatomic distances get closer to that in a $\mathrm{CuZn}$ brass foil. These time-dependent changes in interatomic distances can explain the observed time-dependent changes in the XANES spectra (Figure 4d) as well as the switch in the selectivity. Note that the sensitivity of the $\mathrm{Cu} \mathrm{K}$ edge XANES spectra to interatomic distance changes has been demonstrated in our recent work. ${ }^{58}$ This allows us now to track the changes in the catalyst structure with better time-resolution than what was possible based on the EXAFS analysis. By combining insights from EXAFS and XANES data analyses, we conclude that the interaction (alloying) between the $\mathrm{Cu}$ and $\mathrm{Zn}$ atoms gradually takes place under $\mathrm{CO}_{2} \mathrm{RR}$ conditions, and that it changes the local structure around the $\mathrm{Cu}$ atoms, making it more similar to that of bulk CuZn brass. Importantly, such changes took place in both samples $\left(\mathrm{Cu}_{50} \mathrm{Zn}_{50}\right.$ and $\mathrm{Cu}_{30} \mathrm{Zn}_{70} \mathrm{NPs}$ ), but the local structure around $\mathrm{Cu}$ in the $\mathrm{Zn}$ rich sample after $1 \mathrm{~h}$ of $\mathrm{CO}_{2} \mathrm{RR}$ was already closer to that in the brass $\mathrm{CuZn}$ foil, as suggested by the larger $\mathrm{Cu}-\mathrm{M}$ distance for this sample. Therefore, this result implies that the ratio of the $\mathrm{Cu}$ and $\mathrm{Zn}$ elements and their oxidation state is critical in determining both, the alloying degree immediately after the onset of the $\mathrm{CO}_{2} \mathrm{RR}$, as well as its evolution as a function of time.

Finally, based on the analysis of operando XAFS data we have observed a correlation between the product selectivity of the CuZn NPs and the reduction of the $\mathrm{ZnO}$ species and concomitant $\mathrm{Cu}-\mathrm{Zn}$ alloy formation. It should be noted that there are a number of commonalities between the $\mathrm{CO}_{2}$ electrochemical reduction and the $\mathrm{CO}_{2}$ hydrogenation processes also taking place over $\mathrm{Cu} / \mathrm{ZnO}$ catalysts, where the formation of brass might occur under certain reaction conditions and affect the catalytic selectivity. Since alloying in bimetallic systems induces the change of the geometric (or strain effect) structure, this transformation can lead to the tuning of the product selectivity in CuZn NPs. According to a recent experimental and theoretical study, an expansive strain in the $\mathrm{Cu}$ lattice should result in a more favorable stabilization of the reaction intermediates, leading to the formation of products beyond ${ }^{*} \mathrm{CO} .{ }^{49}$ This expansive $\mathrm{Cu}$ strain could explain the enhanced $\mathrm{CH}_{4}$ selectivity in the $\mathrm{Cu}$-rich $\mathrm{CuZn}$ NPs. Alloy formation, however, results also in a ligand effect and modification of the electronic structure, e.g., in a change of the $d$-band center of the metal atoms. ${ }^{28,29}$ When upon reduction of the $\mathrm{ZnO}$ species a $\mathrm{CuZn}$ alloy is formed, the $d$ band center of $\mathrm{Cu}$ is shifted away from the Fermi level. ${ }^{59}$ Such shift results in a weakening of the binding strength of * $\mathrm{CO}$ due to the occupancy of antibonding states. ${ }^{18,60}$ Therefore, product selectivity in the Zn-rich CuZn NPs seems to be controlled by the ligand effect rather than strain effects, leading to the loss of the functionality of the $\mathrm{Cu}$ site for further reduction of $\mathrm{CO}$ intermediates.

Importantly, our time-dependent XAFS analysis revealed that alloying between $\mathrm{Cu}$ and $\mathrm{Zn}$ atoms gradually takes place upon reduction of the cationic $\mathrm{Zn}$ species. This fact explains why the selectivity of $\mathrm{CO}_{2} \mathrm{RR}$ for $\mathrm{CH}_{4}$ deteriorates over time. In fact, our durability data acquired for the $\mathrm{Cu}_{50} \mathrm{Zn}_{50} \mathrm{NPs}$ showed that the concentration of the initially produced $\mathrm{CH}_{4}$ gradually decreased after $1 \mathrm{~h}$ reaction (Figure $3 \mathrm{c}$ ). In parallel, 
the concentration of $\mathrm{CO}$ slightly increased. This is assigned to the $\mathrm{Cu}-\mathrm{Zn}$ alloy formation and the loss of the $\mathrm{Cu}$ site ability to hydrogenate adsorbed *CO. This result highlights the critical correlation of the structure and composition of the NP surface and the $\mathrm{CO}_{2} \mathrm{RR}$ selectivity. Furthermore, it also implies that maintaining the metallic $\mathrm{Cu}-\mathrm{ZnO}$ interface is vital for the stable production of $\mathrm{CO}_{2}$ products, which can be affected by the reduction of the cationic $\mathrm{Zn}$ species in the $\mathrm{CuZn}$ alloyed catalysts. In conclusion, the product selectivity of CuZn NPs is determined by a combination of geometric and ligand effects, which become more or less prominent depending on the degree of alloying of the $\mathrm{Cu}-\mathrm{Zn}$ species. In the first few hours, when the contribution of the $\mathrm{Cu}-\mathrm{Zn}$ alloy is not significant, $\mathrm{CH}_{4}$ formation over $\mathrm{Cu}-\mathrm{ZnO}$ NPs is observed. Selectivity, however, switches to the formation of a $\mathrm{CO}+\mathrm{H}_{2}$ mix when brass is formed under $\mathrm{CO}_{2} \mathrm{RR}$ conditions. ${ }^{36}$

Considering that our $\mathrm{CuZn} \mathrm{NP} \mathrm{system} \mathrm{was} \mathrm{prepared} \mathrm{as} \mathrm{a}$ model catalyst system, $\mathrm{CH}_{4}$ and $\mathrm{CO}$ are the products to be expected when $\mathrm{Cu}$ is in contact with $\mathrm{ZnO}$ species within a nanoparticle. It is however known from previous studies that small $\mathrm{Cu}$ NPs favor $\mathrm{CO}$ production (and $\mathrm{H}_{2}$ ) over hydrocarbons and alcohols. ${ }^{61}$ Therefore, a comparison with other data in the literature on $\mathrm{Cu}-\mathrm{Zn}$ systems must address two aspects: (i) whether a size effect should be considered and/or (ii) if the investigation has been conducted on a $\mathrm{Cu}-\mathrm{ZnO}$ system or $\mathrm{Cu}-\mathrm{Zn}$ alloy. Interestingly, several previous papers have reported the production of $C_{2}$ products such as ethylene and ethanol in $\mathrm{CuZn}$ catalysts containing $\mathrm{Cu} / \mathrm{ZnO}$ or $\mathrm{CuOx} /$ $\mathrm{ZnO}$ species. ${ }^{33,34}$ Others however reported only $\mathrm{CO}$ and $\mathrm{H}_{2}$ production when the samples investigated consisted of $\mathrm{Cu}-\mathrm{Zn}$ alloys already in the as-prepared state. ${ }^{36}$ Our data serve to consolidate the different findings available in the $\mathrm{Cu}-\mathrm{Zn}$ literature, in particular, to clarify that for bulk-like systems (films and large NPs), $\mathrm{Cu}-\mathrm{Zn}$ alloys will lead to the exclusive production of $\mathrm{CO}$ and $\mathrm{H}_{2}$, while dealloyed $\mathrm{Cu} / \mathrm{ZnO}$ systems might also result in other products such as $\mathrm{CH}_{4}$ for our NPs or even $\mathrm{C}_{2+}$ products for larger material systems.

\section{CONCLUSION}

In summary, we have demonstrated that the product selectivity of $\mathrm{CuZn} \mathrm{NPs} \mathrm{can} \mathrm{be} \mathrm{correlated} \mathrm{with} \mathrm{the} \mathrm{initial} \mathrm{Cu} / \mathrm{Zn}$ ratio as well as with the degree of alloying between the $\mathrm{Cu}$ and $\mathrm{Zn}$ components, which was found to evolve under $\mathrm{CO}_{2} \mathrm{RR}$ conditions. In particular, time-dependent XAFS data revealed that metallic $\mathrm{Cu}$ in close proximity to $\mathrm{ZnO}$ leads to the production of $\mathrm{CH}_{4}$ at the initial stages of the reaction. The progressive reduction of the $\mathrm{ZnO}$ species taking place under $\mathrm{CO}_{2} \mathrm{RR}$ conditions and the concomitant enhanced $\mathrm{Cu}-\mathrm{Zn}$ interaction and brass alloy formation lead to the switch in the selectivity to the exclusive generation of $\mathrm{CO}$ and $\mathrm{H}_{2}$. Our operando spectroscopy study provides crucial information on the nature of the active species and structure of CuZn NP catalysts. We believe that our findings can help to guide the rational design of bimetallic NP catalysts for $\mathrm{CO}_{2} \mathrm{RR}$.

\section{ASSOCIATED CONTENT}

\section{S Supporting Information}

The Supporting Information is available free of charge at https://pubs.acs.org/doi/10.1021/jacs.9b10709.

XAS data and fitting results, AFM images, quasi in situ XPS spectra, and electrochemical data (PDF)

\section{AUTHOR INFORMATION}

\section{Corresponding Author}

*roldan@fhi-berlin.mpg.de

ORCID $\odot$

Beatriz Roldan Cuenya: 0000-0002-8025-307X

Notes

The authors declare no competing financial interest.

\section{ACKNOWLEDGMENTS}

This work was funded by the German Federal Ministry of Education and Research (BMBF) under Grant 03SF0523C (CO2EKAT), the European Research Council under Grant ERC-OPERANDOCAT (ERC-725915), and the Deutsche Forschungsgemeinschaft (DFG, German Research Foundation) under Germany's Excellence Strategy, EXC 2008/1 (UniSysCat), 390540038.

\section{REFERENCES}

(1) Whipple, D. T.; Kenis, P. J. A. Prospects of $\mathrm{CO}_{2}$ Utilization via Direct Heterogeneous Electrochemical Reduction. J. Phys. Chem. Lett. 2010, 1, 3451-3458.

(2) Kondratenko, E. V.; Mul, G.; Baltrusaitis, J.; Larrazabal, G. O.; Perez-Ramirez, J. Status and perspectives of $\mathrm{CO}_{2}$ conversion into fuels and chemicals by catalytic, photocatalytic and electrocatalytic processes. Energy Environ. Sci. 2013, 6, 3112-3135.

(3) Hori, Y. Electrochemical $\mathrm{CO}_{2}$ Reduction on Metal Electrodes. In Modern Aspects of Electrochemistry, Vayenas, C. G., White, R. E., Gamboa-Aldeco, M. E., Eds.; Springer: New York, NY, 2008; pp 89189.

(4) Kim, C.; Jeon, H. S.; Eom, T.; Jee, M. S.; Kim, H.; Friend, C. M.; Min, B. K.; Hwang, Y. J. Achieving Selective and Efficient Electrocatalytic Activity for $\mathrm{CO}_{2}$ Reduction Using Immobilized Silver Nanoparticles. J. Am. Chem. Soc. 2015, 137, 13844-13850.

(5) Mistry, H.; Choi, Y.-W.; Bagger, A.; Scholten, F.; Bonifacio, C. S.; Sinev, I.; Divins, N. J.; Zegkinoglou, I.; Jeon, H. S.; Kisslinger, K.; Stach, E. A.; Yang, J. C.; Rossmeisl, J.; Roldan Cuenya, B. Enhanced Carbon Dioxide Electroreduction to Carbon Monoxide over DefectRich Plasma-Activated Silver Catalysts. Angew. Chem., Int. Ed. 2017, 56, 11394-11398.

(6) Mistry, H.; Varela, A. S.; Bonifacio, C. S.; Zegkinoglou, I.; Sinev, I.; Choi, Y.-W.; Kisslinger, K.; Stach, E. A.; Yang, J. C.; Strasser, P.; Cuenya, B. R. Highly selective plasma-activated copper catalysts for carbon dioxide reduction to ethylene. Nat. Commun. 2016, 7, 12123.

(7) Loiudice, A.; Lobaccaro, P.; Kamali, E. A.; Thao, T.; Huang, B. H.; Ager, J. W.; Buonsanti, R. Tailoring Copper Nanocrystals towards $\mathrm{C}_{2}$ Products in Electrochemical $\mathrm{CO}_{2}$ Reduction. Angew. Chem., Int. Ed. 2016, 55, 5789-5792.

(8) Jeon, H. S.; Kunze, S.; Scholten, F.; Roldan Cuenya, B. PrismShaped $\mathrm{Cu}$ Nanocatalysts for Electrochemical $\mathrm{CO}_{2}$ Reduction to Ethylene. ACS Catal. 2018, 8 (1), 531-535.

(9) Li, Y.; Cui, F.; Ross, M. B.; Kim, D.; Sun, Y.; Yang, P. StructureSensitive $\mathrm{CO}_{2}$ Electroreduction to Hydrocarbons on Ultrathin 5-fold Twinned Copper Nanowires. Nano Lett. 2017, 17, 1312-1317.

(10) Raciti, D.; Livi, K. J.; Wang, C. Highly Dense Cu Nanowires for Low-Overpotential $\mathrm{CO}_{2}$ Reduction. Nano Lett. 2015, 15, 6829-6835.

(11) Saberi Safaei, T.; Mepham, A.; Zheng, X.; Pang, Y.; Dinh, C.-T.; Liu, M.; Sinton, D.; Kelley, S. O.; Sargent, E. H. High-Density Nanosharp Microstructures Enable Efficient $\mathrm{CO}_{2}$ Electroreduction. Nano Lett. 2016, 16, 7224-7228.

(12) Lum, Y.; Yue, B.; Lobaccaro, P.; Bell, A. T.; Ager, J. W. Optimizing $\mathrm{C}-\mathrm{C}$ Coupling on Oxide-Derived Copper Catalysts for Electrochemical $\mathrm{CO}_{2}$ Reduction. J. Phys. Chem. C 2017, 121, 1419114203.

(13) Singh, M. R.; Kwon, Y.; Lum, Y.; Ager, J. W.; Bell, A. T. Hydrolysis of Electrolyte Cations Enhances the Electrochemical 
Reduction of $\mathrm{CO}_{2}$ over $\mathrm{Ag}$ and Cu. J. Am. Chem. Soc. 2016, 138, 13006-13012.

(14) Gao, D.; Scholten, F.; Roldan Cuenya, B. Improved $\mathrm{CO}_{2}$ Electroreduction Performance on Plasma-Activated $\mathrm{Cu}$ Catalysts via Electrolyte Design: Halide Effect. ACS Catal. 2017, 7, 5112-5120.

(15) Varela, A. S.; Ju, W.; Reier, T.; Strasser, P. Tuning the Catalytic Activity and Selectivity of $\mathrm{Cu}$ for $\mathrm{CO}_{2}$ Electroreduction in the Presence of Halides. ACS Catal. 2016, 6, 2136-2144.

(16) Varela, A. S.; Kroschel, M.; Leonard, N. D.; Ju, W.; Steinberg, J.; Bagger, A.; Rossmeisl, J.; Strasser, P. pH Effects on the Selectivity of the Electrocatalytic $\mathrm{CO}_{2}$ Reduction on Graphene-Embedded $\mathrm{Fe}-$ N-C Motifs: Bridging Concepts between Molecular Homogeneous and Solid-State Heterogeneous Catalysis. ACS Energy Lett. 2018, 3, 812-817.

(17) Resasco, J.; Chen, L. D.; Clark, E.; Tsai, C.; Hahn, C.; Jaramillo, T. F.; Chan, K.; Bell, A. T. Promoter Effects of Alkali Metal Cations on the Electrochemical Reduction of Carbon Dioxide. J. Am. Chem. Soc. 2017, 139, 11277-11287.

(18) Kim, D.; Resasco, J.; Yu, Y.; Asiri, A. M.; Yang, P. Synergistic geometric and electronic effects for electrochemical reduction of carbon dioxide using gold-copper bimetallic nanoparticles. Nat. Commun. 2014, 5, DOI: 10.1038/ncomms5948.

(19) Rasul, S.; Anjum, D. H.; Jedidi, A.; Minenkov, Y.; Cavallo, L.; Takanabe, K. A Highly Selective Copper-Indium Bimetallic Electrocatalyst for the Electrochemical Reduction of Aqueous $\mathrm{CO}_{2}$ to $\mathrm{CO}$. Angew. Chem., Int. Ed. 2015, 54, 2146-2150.

(20) Ma, M.; Hansen, H. A.; Valenti, M.; Wang, Z.; Cao, A.; Dong, M.; Smith, W. A. Electrochemical reduction of $\mathrm{CO}_{2}$ on compositionally variant Au-Pt bimetallic thin films. Nano Energy 2017, 42, 51-57.

(21) Morales-Guio, C. G.; Cave, E. R.; Nitopi, S. A.; Feaster, J. T.; Wang, L.; Kuhl, K. P.; Jackson, A.; Johnson, N. C.; Abram, D. N.; Hatsukade, T.; Hahn, C.; Jaramillo, T. F. Improved $\mathrm{CO}_{2}$ reduction activity towards $\mathrm{C}_{2+}$ alcohols on a tandem gold on copper electrocatalyst. Nature Catal. 2018, 1, 764-771.

(22) Luc, W.; Collins, C.; Wang, S.; Xin, H.; He, K.; Kang, Y.; Jiao, F. Ag-Sn Bimetallic Catalyst with a Core-Shell Structure for $\mathrm{CO}_{2}$ Reduction. J. Am. Chem. Soc. 2017, 139, 1885-1893.

(23) Lu, L.; Sun, X.; Ma, J.; Yang, D.; Wu, H.; Zhang, B.; Zhang, J.; Han, B. Highly Efficient Electroreduction of $\mathrm{CO}_{2}$ to Methanol on Palladium-Copper Bimetallic Aerogels. Angew. Chem., Int. Ed. 2018, 57, 14149-14153.

(24) Kortlever, R.; Peters, I.; Koper, S.; Koper, M. T. M. Electrochemical $\mathrm{CO}_{2}$ Reduction to Formic Acid at Low Overpotential and with High Faradaic Efficiency on Carbon-Supported Bimetallic Pd-Pt Nanoparticles. ACS Catal. 2015, 5, 3916-3923.

(25) Cai, Z.; Wu, Y.; Wu, Z.; Yin, L.; Weng, Z.; Zhong, Y.; Xu, W.; Sun, X.; Wang, H. Unlocking Bifunctional Electrocatalytic Activity for $\mathrm{CO}_{2}$ Reduction Reaction by Win-Win Metal-Oxide Cooperation. ACS Energy Lett. 2018, 3, 2816-2822.

(26) Clark, E. L.; Hahn, C.; Jaramillo, T. F.; Bell, A. T. Electrochemical $\mathrm{CO}_{2}$ Reduction over Compressively Strained $\mathrm{CuAg}$ Surface Alloys with Enhanced Multi-Carbon Oxygenate Selectivity. J. Am. Chem. Soc. 2017, 139, 15848-15857.

(27) Sarfraz, S.; Garcia-Esparza, A. T.; Jedidi, A.; Cavallo, L.; Takanabe, K. Cu-Sn Bimetallic Catalyst for Selective Aqueous Electroreduction of $\mathrm{CO}_{2}$ to CO. ACS Catal. 2016, 6, 2842-2851.

(28) Mistry, H.; Varela, A. S.; Kuhl, S.; Strasser, P.; Cuenya, B. R. Nanostructured electrocatalysts with tunable activity and selectivity. Nat. Rev. Mater. 2016, 1, 16009.

(29) Gao, D.; Arán-Ais, R. M.; Jeon, H. S.; Roldan Cuenya, B. Rational catalyst and electrolyte design for $\mathrm{CO}_{2}$ electroreduction towards multicarbon products. Nat. Catal. 2019, 2, 198-210.

(30) Yin, G.; Abe, H.; Kodiyath, R.; Ueda, S.; Srinivasan, N.; Yamaguchi, A.; Miyauchi, M. Selective electro- or photo-reduction of carbon dioxide to formic acid using a $\mathrm{Cu}-\mathrm{Zn}$ alloy catalyst. J. Mater. Chem. A 2017, 5, 12113-12119.

(31) Yin, G.; Sako, H.; Gubbala, R. V.; Ueda, S.; Yamaguchi, A.; Abe, H.; Miyauchi, M. A Cu-Zn nanoparticle promoter for selective carbon dioxide reduction and its application in visible-light-active $\mathrm{Z}$ - scheme systems using water as an electron donor. Chem. Commun. 2018, 54, 3947-3950.

(32) Hu, H.; Tang, Y.; Hu, Q.; Wan, P.; Dai, L.; Yang, X. J. In-situ grown nanoporous $\mathrm{Zn}$-Cu catalysts on brass foils for enhanced electrochemical reduction of carbon dioxide. Appl. Surf. Sci. 2018, $445,281-286$.

(33) Keerthiga, G.; Chetty, R. Electrochemical Reduction of Carbon Dioxide on Zinc-Modified Copper Electrodes. J. Electrochem. Soc. 2017, 164, H164-H169.

(34) Ren, D.; Ang, B. S.-H.; Yeo, B. S. Tuning the Selectivity of Carbon Dioxide Electroreduction toward Ethanol on Oxide-Derived CuxZn Catalysts. ACS Catal. 2016, 6, 8239-8247.

(35) Feng, Y.; Li, Z.; Liu, H.; Dong, C.; Wang, J.; Kulinich, S. A.; $\mathrm{Du}, \mathrm{X}$. Laser-Prepared CuZn Alloy Catalyst for Selective Electrochemical Reduction of $\mathrm{CO}_{2}$ to Ethylene. Langmuir 2018, 34, 1354413549.

(36) Lamaison, S.; Wakerley, D.; Montero, D.; Rousse, G.; Taverna, D.; Giaume, D.; Mercier, D.; Blanchard, J.; Tran, H. N.; Fontecave, M.; Mougel, V. Zn-Cu Alloy Nanofoams as Efficient Catalysts for the Reduction of $\mathrm{CO}_{2}$ to Syngas Mixtures with a Potential-Independent $\mathrm{H}_{2}$ /CO Ratio. ChemSusChem 2019, 12, 511-517.

(37) Li, C. W.; Kanan, M. W. $\mathrm{CO}_{2}$ Reduction at Low Overpotential on $\mathrm{Cu}$ Electrodes Resulting from the Reduction of Thick $\mathrm{Cu}_{2} \mathrm{O}$ Films. J. Am. Chem. Soc. 2012, 134, 7231-7234.

(38) Verdaguer-Casadevall, A.; Li, C. W.; Johansson, T. P.; Scott, S. B.; McKeown, J. T.; Kumar, M.; Stephens, I. E. L.; Kanan, M. W.; Chorkendorff, I. Probing the Active Surface Sites for CO Reduction on Oxide-Derived Copper Electrocatalysts. J. Am. Chem. Soc. 2015, 137, 9808-9811.

(39) Mariano, R. G.; McKelvey, K.; White, H. S.; Kanan, M. W. Selective increase in $\mathrm{CO}_{2}$ electroreduction activity at grain-boundary surface terminations. Science 2017, 358, 1187-1192.

(40) Ma, M.; Djanashvili, K.; Smith, W. A. Controllable Hydrocarbon Formation from the Electrochemical Reduction of $\mathrm{CO}_{2}$ over Cu Nanowire Arrays. Angew. Chem. 2016, 128, 6792-6796.

(41) Schouten, K. J. P.; Pérez Gallent, E.; Koper, M. T. M. The influence of $\mathrm{pH}$ on the reduction of $\mathrm{CO}$ and to hydrocarbons on copper electrodes. J. Electroanal. Chem. 2014, 716, 53-57.

(42) Kim, B.; Ma, S.; Molly Jhong, H.-R.; Kenis, P. J. A. Influence of dilute feed and $\mathrm{pH}$ on electrochemical reduction of $\mathrm{CO}_{2}$ to $\mathrm{CO}$ on $\mathrm{Ag}$ in a continuous flow electrolyzer. Electrochim. Acta 2015, 166, 271276.

(43) Favaro, M.; Xiao, H.; Cheng, T.; Goddard, W. A.; Yano, J.; Crumlin, E. J. Subsurface oxide plays a critical role in $\mathrm{CO}_{2}$ activation by $\mathrm{Cu}(111)$ surfaces to form chemisorbed $\mathrm{CO}_{2}$, the first step in reduction of $\mathrm{CO}_{2}$. Proc. Natl. Acad. Sci. U. S. A. 2017, 114, 67066711.

(44) Choi, Y.-W.; Scholten, F.; Sinev, I.; Roldan Cuenya, B. Enhanced stability and $\mathrm{CO} /$ Formate selectivity of plasma-treated $\mathrm{SnO}_{\mathrm{x}} / \mathrm{AgO}_{\mathrm{x}}$ catalysts during $\mathrm{CO}_{2}$ electroreduction. J. Am. Chem. Soc. 2019, 141, 5261-5266.

(45) Lee, S. Y.; Jung, H.; Kim, N.-K.; Oh, H.-S.; Min, B. K.; Hwang, Y. J. Mixed Copper States in Anodized Cu Electrocatalyst for Stable and Selective Ethylene Production from $\mathrm{CO}_{2}$ Reduction. J. Am. Chem. Soc. 2018, 140, 8681-8689.

(46) Mistry, H.; Behafarid, F.; Reske, R.; Varela, A. S.; Strasser, P.; Roldan Cuenya, B. Tuning catalytic selectivity at the mesoscale via interparticle interactions. ACS Catal. 2016, 6, 1075-1080.

(47) Mistry, H.; Reske, R.; Strasser, P.; Roldan Cuenya, B. Sizedependent reactivity of gold-copper bimetallic nanoparticles during $\mathrm{CO}_{2}$ electroreduction. Catal. Today 2017, 288, 30-36.

(48) Ravel, B.; Newville, M. ATHENA, ARTEMIS, HEPHAESTUS: data analysis for X-ray absorption spectroscopy using IFEFFIT. $J$. Synchrotron Radiat. 2005, 12, 537-541.

(49) Bernal, M.; Bagger, A.; Scholten, F.; Sinev, I.; Bergmann, A.; Ahmadi, M.; Rossmeisl, J.; Cuenya, B. R. $\mathrm{CO}_{2}$ electroreduction on copper-cobalt nanoparticles: Size and composition effect. Nano Energy 2018, 53, 27-36. 
(50) Biesinger, M. C.; Payne, B. P.; Grosvenor, A. P.; Lau, L. W. M.; Gerson, A. R.; Smart, R. S. C. Resolving surface chemical states in XPS analysis of first row transition metals, oxides and hydroxides: $\mathrm{Cr}$, $\mathrm{Mn}, \mathrm{Fe}, \mathrm{Co}$ and Ni. Appl. Surf. Sci. 2011, 257, 2717-2730.

(51) Jeon, H. S.; Sinev, I.; Scholten, F.; Divins, N. J.; Zegkinoglou, I.; Pielsticker, L.; Cuenya, B. R. Operando Evolution of the Structure and Oxidation State of Size-Controlled $\mathrm{Zn}$ Nanoparticles during $\mathrm{CO}_{2}$ Electroreduction. J. Am. Chem. Soc. 2018, 140, 9383-9386.

(52) Kortlever, R.; Shen, J.; Schouten, K. J. P.; Calle-Vallejo, F.; Koper, M. T. M. Catalysts and Reaction Pathways for the Electrochemical Reduction of Carbon Dioxide. J. Phys. Chem. Lett. 2015, 6, 4073-4082.

(53) Zhang, Y.-J.; Sethuraman, V.; Michalsky, R.; Peterson, A. A. Competition between $\mathrm{CO}_{2}$ Reduction and $\mathrm{H}_{2}$ Evolution on Transition-Metal Electrocatalysts. ACS Catal. 2014, 4, 3742-3748.

(54) Peterson, A. A.; Abild-Pedersen, F.; Studt, F.; Rossmeisl, J.; Norskov, J. K. How copper catalyzes the electroreduction of carbon dioxide into hydrocarbon fuels. Energy Environ. Sci. 2010, 3, 13111315.

(55) Kuhl, K. P.; Cave, E. R.; Abram, D. N.; Jaramillo, T. F. New insights into the electrochemical reduction of carbon dioxide on metallic copper surfaces. Energy Environ. Sci. 2012, 5, 7050-7059.

(56) Manthiram, K.; Beberwyck, B. J.; Alivisatos, A. P. Enhanced Electrochemical Methanation of Carbon Dioxide with a Dispersible Nanoscale Copper Catalyst. J. Am. Chem. Soc. 2014, 136, 1331913325 .

(57) Owen, E. A.; Preston, G. D. X-ray analysis of zinc-copper alloys. Proc. Phys. Soc. 1923, 36, 49-66.

(58) Timoshenko, J.; Halder, A.; Yang, B.; Seifert, S.; Pellin, M. J.; Vajda, S.; Frenkel, A. I. Subnanometer Substructures in Nanoassemblies Formed from Clusters under a Reactive Atmosphere Revealed Using Machine Learning. J. Phys. Chem. C 2018, 122, 21686-21693.

(59) Andrews, P. T.; Hisscott, L. A. X-ray photoelectron spectroscopy of some Cu-Zn alloys. J. Phys. F: Met. Phys. 1975, 5, $1568-1572$.

(60) Liu, K.; Ma, M.; Wu, L.; Valenti, M.; Cardenas-Morcoso, D.; Hofmann, J. P.; Bisquert, J.; Gimenez, S.; Smith, W. A. Electronic Effects Determine the Selectivity of Planar $\mathrm{Au}-\mathrm{Cu}$ Bimetallic Thin Films for Electrochemical $\mathrm{CO}_{2}$ Reduction. ACS Appl. Mater. Interfaces 2019, 11, 16546-16555.

(61) Reske, R.; Mistry, H.; Behafarid, F.; Roldan Cuenya, B.; Strasser, P. Particle Size Effects in the Catalytic Electroreduction of $\mathrm{CO}_{2}$ on $\mathrm{Cu}$ Nanoparticles. J. Am. Chem. Soc. 2014, 136, 6978-6986. 